\title{
Analisis Pembangkit Listrik Berbasis Flywheel
}

\author{
Jumadi Tangko $^{1^{*}}$, Remigius Tandioga $^{2}$, Ismail Djufri $^{3}$, Riza Haardiyanti $^{4}$ \\ 1,2,3,4 Jurusan Teknik Mesin, Politeknik Negeri Ujung Pandang, Makassar 90245, Indonesia \\ *jumadi_tangko@poliupg.ac.id
}

\begin{abstract}
Flywheel is a rotating mechanical device, which is generally used on four-wheeled vehicles. Flywheel has a moment of inertia that is able to withstand changes in rotational speed. The energy in flywheel is mechanical energy. This mechanical energy will be converted by generators into electrical energy. At the flywheel-based power plant, tests are carried out in the form of rotation, the generator power of the generator under no load or load conditions, and the time needed for this generator to survive. The results showed that the ability of the flywheel-based power plant in the condition without a backup supply to the motor in the condition of a generator without a load is able to generate power of $860.1 \mathrm{~W}$ for 22 seconds, while in a load-bearing generator capable of generating electricity by $708.75 \mathrm{~W}$ for 18 seconds
\end{abstract}

Keywords: Flywheel, Mechanical Energy, Electrical Energy, Moment of Inertia

\begin{abstract}
Abstrak: Flywheel merupakan perangkat mekanik berputar, yang pada umumnya digunakan pada kendaraan roda empat. Flywheel memiliki momen inersia yang mampu menahan perubahan kecepatan rotasi. Energi yang ada pada flywheel adalah energi mekanik. Energi mekanik inilah yang akan diubah oleh generator menjadi energi listrik. Pada pembangkit listrik berbasis flywheel dilakukan pengujian berupa putaran, daya pembangkitan generator dalam keadaan tanpa beban maupun keadaan berbeban, dan waktu yang dibutuhkan pembangkit ini untuk bertahan. Hasil penelitian menunjukkan bahwa kemampuan pembangkit listrik berbasis flywheel pada kondisi tanpa suplai cadangan untuk motor dalam keadaan generator tanpa beban mampu membangkitkan daya sebesar 860,1 W selama 22 detik, sedangkan dalam keadaan generator berbeban mampu membangkitkan listrik sebesar 708,75 W selama 18 detik
\end{abstract}

Kata kunci : Flywheel, Energi Mekanik, Energi Listrik, Momen Inersia

\section{PENDAHULUAN}

Energi listrik dikatakan sebagai kebutuhan pokok bagi masyarakat pada zaman globalisasi sekarang. Semakin berkembangnya teknologi maka semakin tinggi pula kebutuhan listrik yang dibutuhkan masyarakat. Akan tetapi tingkat kebutuhan masyarakat yang semakin tinggi ini nampaknya tidak diikuti dengan ketersediaan energi listrik yang ada. Salah satu energi alternatif adalah pemanfaatan roda gila (flywheel). Pemanfaatan yang dimaksudkan disini yaitu menjadikan energi kinetik yang tersimpan pada flywheel dimanfaatkan kembali untuk memutar generator.

Pembangkit listrik berbasis flywheel terdiri dari dua bagian yaitu mesin pembangkit dan sistem suplai cadangan untuk motor. Mesin pembangkit yang terdiri atas motor induksi satu fasa yang mengkopel flywheel dan generator ac satu fasa yang dikopel dari flywheel pada dasarnya menggunakan prinsip kerja konversi energi dari energi mekanik (energi gerak) yang tersimpan pada flywheel dan meneruskan energi kinetik tersebut ke generator sehingga menjadi energi listrik, selama motor induksi satu-fasanya mendapat suplai yang kontinu. Jika suplai jala-jala untuk motor dilepaskan dalam keadaan generator sudah bertegangan, maka generator akan mengalami pengereman regeneratif. Sistem suplai cadangan untuk motor yang terdiri dari inverter, aki dan penyearah dibutuhkan untuk menampung energi listrik yang dihasilkan mesin pembangkit untuk menyuplai motor kembali. Pembangkit listrik berbasis flywheel ini tidak menggunakan sistem suplai cadangan untuk motor dikarenakan penulis hanya ingin terfokus pada kemampuan mesin pembangkitnya untuk menghasilkan listrik. Berdasarkan uraian tersebut, maka artikel ini bertujuan untuk menganalisis pembangkit listrik yang berbasiskan Flywheel". 
78 Jumadi Tangko, Remigius Tandioga, Ismail Djufri, Riza Haardiyanti. Analisis Pembangkit Listrik Berbasis Flywheel

\section{A. Pembangkit Listrik Berbasis Flywheel}

Pembangkit Listrik Berbasis Flywheel adalah pembangkit yang mengandalkan energi kinetik dari flywheel menghasilkan energi listrik.

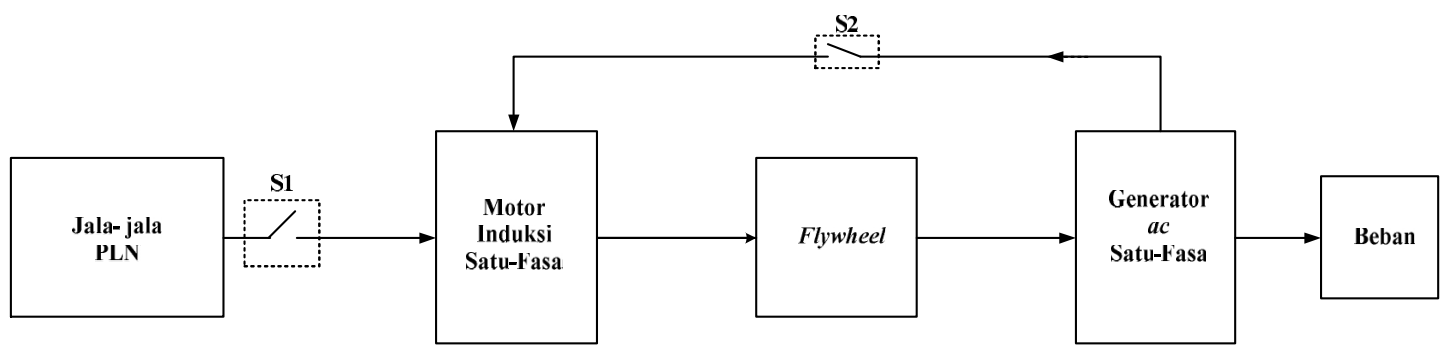

Gambar 1. Diagram blok sistem pembangkit listrik berbasis flywheel.

Ide dari pembangkit listrik seperti pada Gambar 1 adalah bahwa pada awalnya hanya saklar S1 yang tertutup. Jadi motor memutar flywheel dan flywheel memutar generator hingga generator membangkitkan tegangan. Ketika saklar S1 dibuka dan S2 ditutup maka diharapkan bahwa energi sisa yang tersimpan di flywheel akan masih cukup untuk memutar generator sehingga generator mempunyai tegangan yang cukup untuk mensuplai motor. Motor akan kembali mensuplai flywheel dengan torsi yang cukup. Demikian seterusnya sampai berlangsung proses pembangkitan listrik yang cukup di generator secara terus menerus dan proses pembangkitan energi mekanik yang cukup di motor inilah yang dinamakan pembangkit listrik berbasis flywheel.

\section{B. Proses Konversi Energi.}

1. Energi Kinetik

Energi kinetik adalah energi yang dimiliki benda karena geraknya. Makin besar kecepatan benda bergerak makin besar energi kinetiknya dan semakin besar massa benda yang bergerak makin besar pula energi kinetik yang dimilikinya. Untuk menghitung energi kinetik sebuah benda maka digunakan persamaan :

$$
\mathrm{Ek}=1 / 2 \mathrm{I} \omega^{2}
$$

Dimana $\mathrm{E}_{\mathrm{k}}=$ Energi kinetik $(\mathrm{J}), \mathrm{I}=$ Momen inersia flywheel $\left(\mathrm{kg} \cdot \mathrm{m}^{2}\right), \omega=$ kecepatan sudut flywheel $(\mathrm{rad} / \mathrm{s})$

Flywheel merupakan benda yang memiliki massa dan dapat berputar maka dari itu flywheel memiliki energi kinetik rotasi, selain itu flywheel memiliki kemampuan untuk masih menyimpan energi ketika suplai diputuskan, maka dari itu energi kinetik yang tersimpan tersebut bisa dikonversi menjadi energi listrik.

2. Energi Listrik

Energi listrik adalah salah satu jenis energi utama yang digunakan untuk menghidupkan peralatan-peralatan listrik. Sedangkan daya listrik adalah energi listrik per satuan waktu. Untuk mengetahui besaran daya listrik maka digunakan persamaan

$$
\mathrm{P}=\mathrm{V} . \mathrm{I}
$$

Dimana : P = Daya (W), V = Tegangan (V), I = Arus (A)

Dalam satuan SI satu watt didefinisikan sebagai satuan yang sama dengan kerja yang dilakukan pada satu joule setiap sekon. Untuk mengkonversi energi mekanik menjadi energi listrik dibutuhkan sebuah peralatan yang disebut dengan generator listrik.

\section{Komponen Pembangkit Listrik Berbasis Flywheel.}

Pembangkit listrik berbasis flywheel terdiri dari : motor, flywheel, dan generator yang terkopel satu sama lain dengan menggunakan transmisi mekanik. Transmisi mekanik yang digunakan pada 
pembangkit listrik berbasis flywheel terdiri atas beberapa komponen antara lain : poros, bantalan, sabuk V dan puli. Rangkaian pembangkit listrik berbasis flywheel dapat dilihat pada gambar 2.

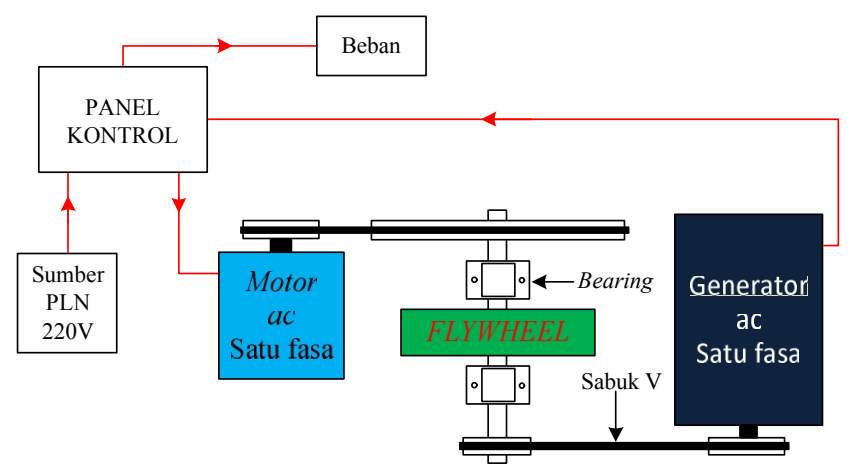

Gambar 2.Rangkaian pembangkit listrik berbasis flywheel tanpa mekanisme suplai cadangan untuk motor

\section{METODE PENELITIAN}

\section{A. Tempat dan Waktu Penelitian}

Waktu pengerjaan tugas akhir dimulai dari bulan Juni sampai Agustus 2016. Tugas akhir ini dilakukan di Bengkel Mekanik Politeknik Negeri Ujung pandang dan Bengkel Mekanik Sejuk Alam Teknik.

\section{B. Teknik pengumpulan Data}

Dalam tahap ini dilakukan pengujian yang bertujuan untuk menguji alat yang telah dirakit atau yang sudah dapat dioperasikan. Berikut langkah-langkah prosedur pengujian pembangkit listrik berbasis flywheel antara lain:

- Memberikan suplai listrik dari PLN ke motor.

- Memastikan putaran motor,flywheel telah stabil

- Memutuskan suplai listrik PLN ke motor.

- Mencatat hasil pengujian berupa variabel yang terkait dengan penelitian.

- Dilakukan pula pengujian pendahuluan terhadap putaran motor, flywheel dan generator

Setelah proses pengujian dilakukan maka data-data yang didapatkan akan dianalisa, hasil analisa akan menunjukkan layak atau tidaknya pembangkit ini. Dengan melihat hasil analisa data maka akan disimpulkan apakah pembuatan pembangkit listrik berbasis flywheel ini berhasil sebagai salah satu pembangkit litrik alternatif atau tidak. 
80 Jumadi Tangko, Remigius Tandioga, Ismail Djufri, Riza Haardiyanti. Analisis Pembangkit Listrik Berbasis Flywheel

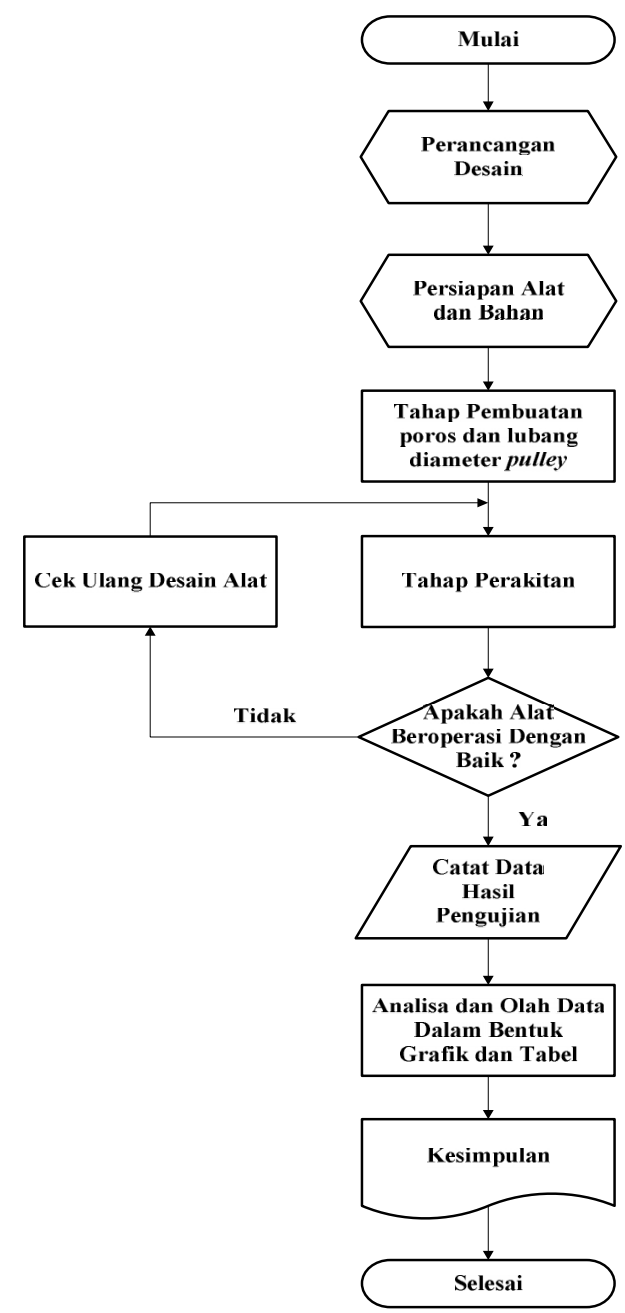

Gambar 3. diagram alir penelitian

\section{HASIL DAN PEMBAHASAN}

A. Hasil

1. Hasil Pengujian Pembangkit Listrik Berbasis Flywheel pada kondisi tanpa suplai cadangan untuk motor dalam keadaan generator tanpa beban dan berbeban dalam bentuk grafik.

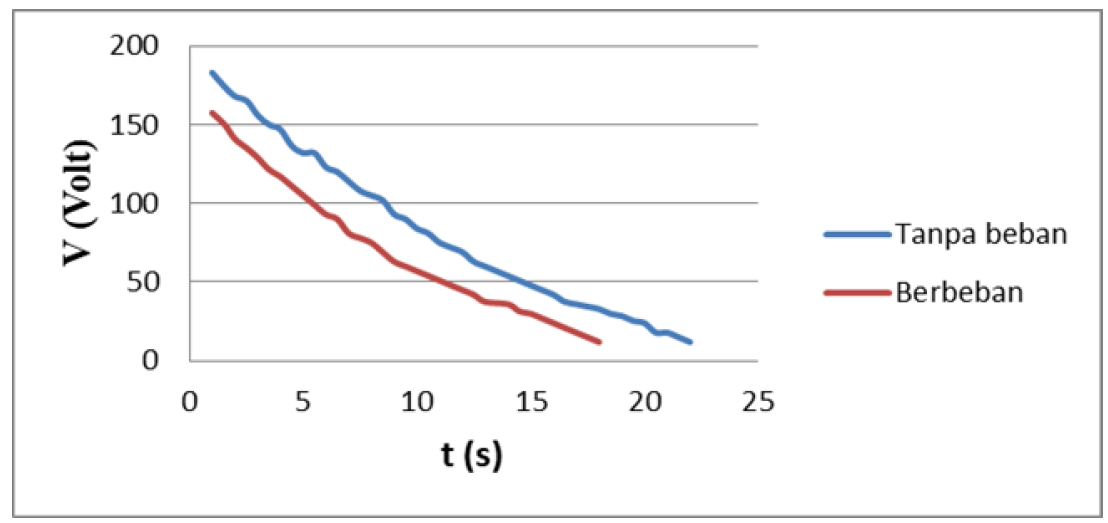


Gambar 4. Kurva lama pembangkitan tegangan generator pada saat suplai listrik ke motor diputus dalam keadaan generator tanpa beban dan berbeban.

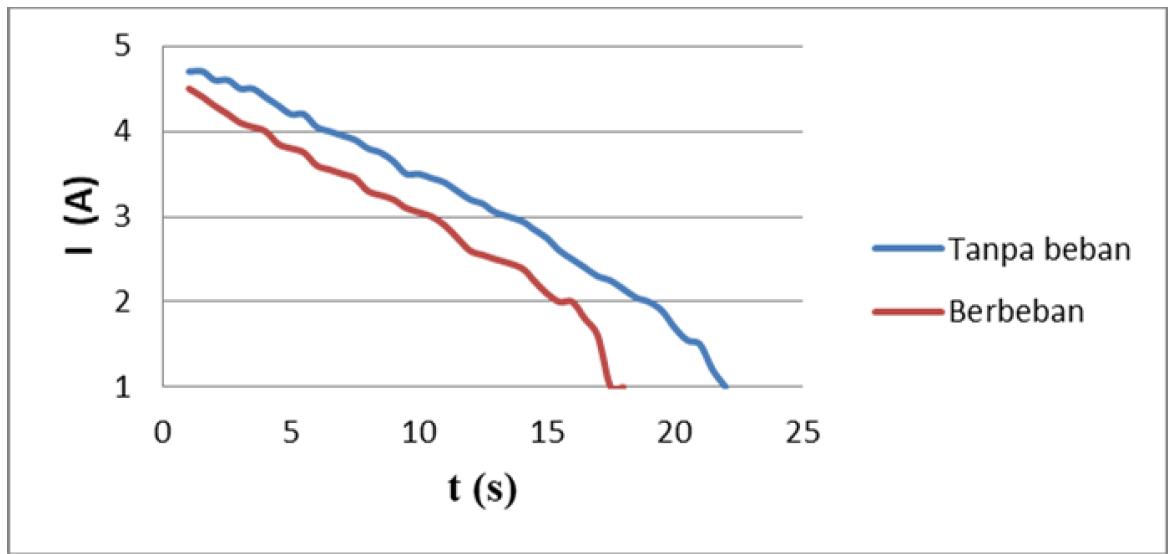

Gambar 5. Kurva lama pembangkitan arus generator pada saat suplai listrik ke motor diputus dalam keadaan generator tanpa beban dan berbeban

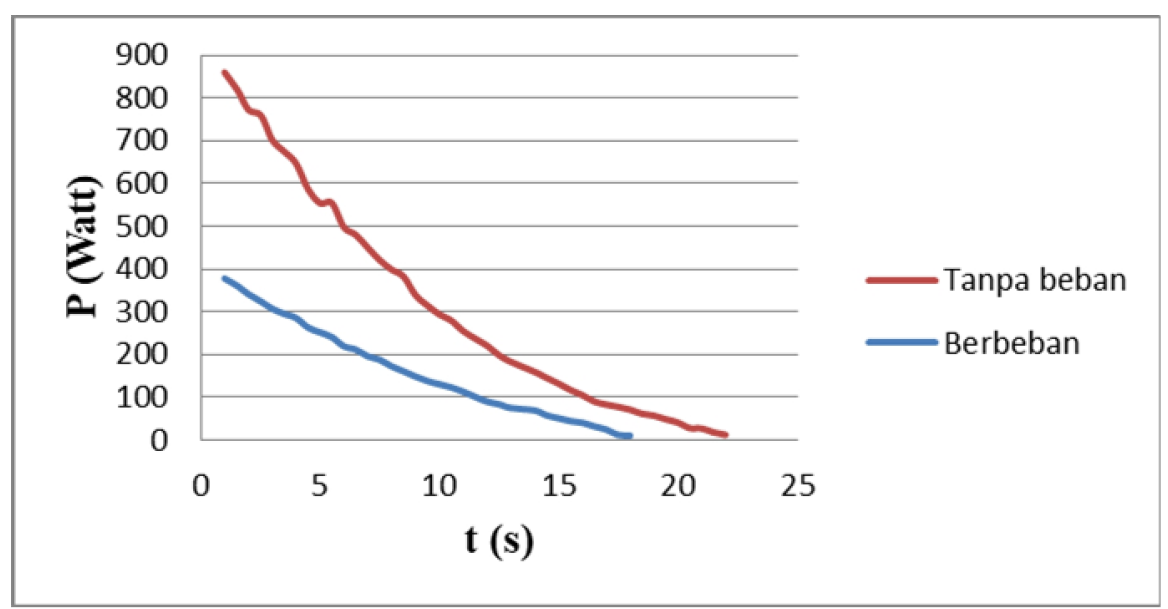

Gambar 6. Kurva lama pembangkitan daya generator pada saat suplai listrik ke motor diputus dalam keadaan generator tanpa beban dan berbeban.

2. Analisis Kinerja Pembangkit Listrik Berbasis Flywheel.

Tabel 1. Daya komponen pembangkit listrik berbasis flywheel.

\begin{tabular}{|c|c|c|}
\hline Komponen & $\mathrm{P}_{\text {aktual }}(\mathrm{W})$ & $\mathrm{P}_{\text {terukur }}$ \\
\hline Motor & 1677,6 & 1760 \\
\hline Flywheel & 726,29 & 649,03 \\
\hline Generator & 1923,11 & 860,1 \\
\hline
\end{tabular}

Dari data tersebut maka rugi-rugi pada setiap perpindahan energi dapat diketahui sebagai berikut :

- $\quad$ Rugi-Rugi Motor $=\mathrm{P}_{\text {aktual }}-\mathrm{P}_{\text {terukur }}$

- Rugi-Rugi Flywheel $=\mathrm{P}_{\text {aktual }}-\mathrm{P}_{\text {terukur }}$

$$
=1677,6-1760 \quad=82,4 \mathrm{~W}
$$

- $\quad$ Rugi-Rugi Generator $=\mathrm{P}_{\text {aktual }}-\mathrm{P}_{\text {terukur }}$

$$
=726,29-649,03 \quad=77,26 \mathrm{~W}
$$

$$
=1923,11-860,1=1063,01 \mathrm{~W}
$$


82 Jumadi Tangko, Remigius Tandioga, Ismail Djufri, Riza Haardiyanti. Analisis Pembangkit Listrik Berbasis Flywheel

- Rugi-Rugi Total = Rugi-Rugi (Motor + Flywheel + Generator)

$=82,4+77,26+1063,11$

$=2817,87 \mathrm{~W}$

Sehingga efisiensi dapat diketahui dengan menggunakan persamaan sebagai berikut :

$$
\begin{aligned}
& \eta=\frac{P_{\text {gen }}}{\text { Rugi }- \text { Rugi Total }} \times 100 \% \\
& =\frac{860,1}{2817,87} \times 100 \% \\
& =30 \%
\end{aligned}
$$

\section{B. PEMBAHASAN}

Berdasarkan hasil perhitungan pada Tabel 1, kemampuan pembangkit listrik berbasis flywheel pada kondisi tanpa suplai cadangan motor keadaan tanpa beban mampu membangkitkan daya hingga 860,1 W. Namun waktu pembangkitan daya pada generator hanya selama 22 detik. Hal ini dikarenakan suplai listrik untuk motor diputus pada keadaan generator bertegangan, sehingga generator mengalami pengereman regeneratif. Dengan waktu yang sangat singkat tersebut daya yang dihasilkan pembangkit ini tidak mampu jika langsung digunakan melainkan harus ditampung terlebih dahulu di $a c c u$ (aki) untuk bisa digunakan lagi.

Berdasarkan hasil perhitungan pada Tabel 1 pengujian dilakukan dengan memberikan beban berupa tahanan jangkar $75 \Omega$. Kemampuan pembangkit listrik berbasis flywheel pada kondisi tanpa suplai cadangan motor keadaan berbeban mampu membangkitkan daya hingga 708,75 W selama 18 detik setelah sumber energi listrik diputus, kondisi tersebut menunjukkan dengan adanya beban yang diberikan maka kemampuan pembangkit listrik berbasis flywheel ini menjadi lebih singkat. Pada kondisi suplai listrik untuk motor diputus pada saat generator tersebut bertegangan maka generator mengalami pengereman regeneratif.

Pada analisis rugi-rugi pada pembangkit listrik berbasis flywheel didapatkan rugi-rugi keseluruhan pembangkit adalah $2817,87 \mathrm{~W}$, rugi-rugi tersebut juga menjadi faktor yang menyebabkan pembangkit listrik berbasis flywheel tidak mampu bertahan lama dikarenakan lebih banyak energi yang terbuang secara percuma.

\section{KESIMPULAN}

Dilihat dari hasil pengujian pembangkit listrik berbasis flywheel, maka dapat disimpulkan :

- Kemampuan sistem pembangkit listrik berbasis flywheel pada kondisi tanpa suplai cadangan untuk motor dalam keadaan generator tanpa beban hanya mampu membangkitkan daya maksimum sebesar 860,1 W selama 22 detik. Hal ini disebabkan tidak adanya suplai cadangan untuk motor sehingga mengakibatkan terjadinya pengereman regeneratif pada generator.

- Kemampuan sistem pembangkit listrik berbasis flywheel pada kondisi tanpa suplai cadangan unntuk motor dalam keadaan generator berbeban hanya mampu membangkitkan daya maksimum sebesar 708,75 W selama 18 detik, hal ini menunjukkan dengan pemberian beban pada generator mengakibatkan kemampuan pembangkit ini membangkitkan semakin singkat.

- Rugi-rugi total pada pembangkit listrik berbasis flywheel adalah sebesar 2817,87 W dengan efisiensi $30 \%$.

\section{DAFTAR PUSTAKA}

[1] Anonim. 2011. Free Flywheel Generator, (Online), (https://ffge.wordpress.com/html, diakses pada 9 Oktober 2015).

[2] Hardianto, Triwahju. dkk. 2013. Penelitian Awal Pemulihan Energi Kinetik Pada Sistem Pengereman Regeneratif Mobil Listrik, (Online), (GoogleSchoolar/ PenelitianAwalPemulihanEnergiKinetikPadaSistemPengeremanRegeneratif MobilListrik.html, diakses pada 27 September 2016). 
[3] Mulyadi, Musradi. 2010. Mekanika Teknik 2 : Elemen Mesin. Politeknik Negeri Ujung Pandang. Makassar.

[4] Murdianto Bayu O. Dkk. 2012. Pengembangan Model "Regenerative Brake" pada Sepeda Listrik untuk Menambah Jarak Tempuh. Jurnal Teknik Pomits, (Online), Vol. 1, No. 2 (digilib.its.ac.id/public/ITS-paper-40026-2109100002-paper.pdf, diakses pada 27 September 2016).

[5] Prastiyo Willy, 2013. Fungsi, Cara Kerja, dan Karakteristik Roda Gila (Flywheel), (Online), (autoonlineschool.blogspot.com/flywheel.html, diakses pada 11 Februari 2016).

[6] Sarojo Aby Ganijanti. 2002. Mekanika. Jakarta: Penerbit Salemba Teknika.

[7] Saferi Rozi. Analisa Roda Daya (Flywheel). (Online), (www.slideserve.com/selma/dinamikateknik/html, diakses pada 11 Februari 2016).

[8] Shingley E.Joseph, dkk. 1986. Perencanaan Teknik Mesin. Jakarta: Penerbit Erlangga.

[9] Trisnaningtyas Buda A. Dkk. 2012. Pengembangan Model "Regenerative Brake" pada Sepeda Listrik untuk Menambah Jarak Tempuh dengan Variasi Kecepatan. Jurnal Teknik Pomits, (Online), Vol. 1, No. 2 (digilib.its.ac.id/public/ITS-paper-29368-2109100066-paper.pdf, diakses pada 27 September 2016). 